\title{
The Revolutionary Chora in Seamus Heaney's Kite Poetry
}

\author{
Hannah Spruce \\ Independent Scholar, Leeds, England
}

Copyright (c) 2016 by Hannah Louise Spruce. This text may be archived and redistributed both in electronic form and in hard copy, provided that the author and journal are properly cited and no fee is charged for access.

\begin{abstract}
This paper examines the presence and impact of the Kristevan chora in the kite poetry of Seamus Heaney, demonstrating how the presence of the chora in his final kite poem "A Kite for Aibhín" is used to alter the discursive representation of fatherhood that was handed down to Heaney through symbolic language. The views of Heaney and Kristeva on the revolutionary potential of poetry is analysed alongside Heaney's poetry to glean an understanding of how poetry has a profound impact on identity and representation. This paper proves that for Heaney poetry afforded weighty individual change, acting as a technological medium through which he could alter language.
\end{abstract}

Key Words. Seamus Heaney, Julia Kristeva, Poetry, Poetics, Gender, The Maternal, Language, The Chora.

Resumen. El artículo analiza la presencia y el impacto de la chora kristeviana en la poesía en torno a cometas de Seamus Heaney, demostrando cómo la presencia de la chora en "Un cometa para Aibhín", su último poema sobre esta temática, sirve para alterar la representación discursiva de la paternidad que Heaney había adquirido a través del lenguaje simbólico. Los puntos de vista de Heaney y Kristeva sobre el potencial revolucionario de la poesía se analizan en relación a la obra poética de Heaney con el propósito de dilucidar el profundo impacto de la poesía en la identidad y la representación. En este trabajo se demuestra que la poesía permitió a Heaney un cambio substancial a nivel individual, al actuar como medio tecnológico a través del cual podía alterar el lenguaje.

Palabras clave. Seamus Heaney, Julia Kristeva, poesía, poética, género, lo maternal, lenguaje, la chora.

In Seamus Heaney's final collection Human Chain, and most explicitly in the last poem of this collection "A Kite for Aibhín", Heaney reveals a corrective move into an inclusive maternal space. His poetry attempts to rectify the socially constructed model of paternal behaviour received through his father and through his culture. He does this through a move to a more maternal poetic space. It is necessary to clarify that this use of the term "maternal" is problematic due to the unavoidable inference of the female sex, motherhood and birth. Calling his poetry maternal is an insufficient expression of the feeling expressed by Heaney in his last kite poem. The limitations of the language available highlight the need for a new, more maternal, yet less gender specific language to describe paternal feelings and relation- 
ships like those present in Heaney's poetry. However, at this time, it is necessary to describe Heaney's poetry as maternal since it is impossible to discuss Kristeva's concept of the chora and use the term "paternal', as this suggests precisely the patriarchal regulation Kristeva is agitating against. Thus, when I speak of Heaney's move to the maternal, I am speaking outside of gender identity. I refer to Kristeva's concept of the "chora" as a genderless repository of drives and energies that are characteristically "nourishing and maternal" (Kristeva 1984: 94).

"A Kite for Aibhín" echoes Giovanni Pascoli's "L'Aquilone", the poem was shown to Heaney by Professor Morisco on a trip to the Italian University of Urbino. In a reflection on her meeting with Heaney called "Two Poets and a Kite" Morisco discloses her realisation of "how dear this topic was to him and how it tied in with his own personal experiences" (Morisco 2013: 35), as the poet had flown kites in his youth and written "A Kite for Michael and Christopher'. In his foreword to the translation of "L'Aquilone" Heaney claims that Morisco:

knew that Yeats's phrase lurked in the Italian text and knew moreover that I had written my own kite poem ('A Kite for Michael and Christopher'). Sooner or later, therefore, I was bound to go "fishing in the sky" (as the Chinese put it) one more time (Heaney 2012).

This "fishing in the sky" led Heaney to rework "L'Aquilone". This revision appeared in Human Chain as the last poem in the collection "A Kite for Aibhín", and "was written to salute the birth of Heaney's second granddaughter" (Sonzogni 2014: 35). It is this final reworked and highly intertextual poem that becomes the pivotal focus of this essay, alongside theory from Julia Kristeva's Revolution in Poetic Language.

"A Kite for Aibhín" demonstrates how Heaney's late style reveals a development in poetic language, a development which we could term "revolutionary". A comparison of his kite poem for Aibhín against the poem for Michael and Christopher reveals a poetic style that in his later years, is uninhibited by those symbolic structures which castrate language, and thus, relationships. This "revolution" is Heaney's ability to express maternal love through poetic language; his ability to put "feelings into words" (Higgins 2014: 72). In his kite poems, the kite as a memory, a motif, and an action is a multifaceted symbol of Heaney's feelings being transposed into words.

Firstly, I wish to illuminate the interconnecting theoretical ideas in both Heaney and Kristeva's poetics. Heaney's The Redress of Poetry and Kristeva's Revolution in Poetic Language share an underlying assertion; that the revolutionary ability of poetry lies in its "liberating and verifying effect upon the individual spirit" (Heaney 1989: 2), in fact, through corrective poetry Heaney's work generates his own liberation. As Anne-Marie Smith observes Kristeva's revolution is an internal and individual revolution where the "subversive work of the semiotic" (Smith 1998: 18) infiltrates the symbolic elements of speech which are patriarchal and isolating, for Kristeva:

All imaginative practice, such as art, poetry, love and psychoanalysis, represents the individual subject's encounter with the law of the father, of the symbolic and of society, with imposed form and structure as well as representing the imaginative attempts to battle with this frame of reference in the name of desire, subjectivity and the energy and drives they bring into play (Smith 1998: 18).

The arrangement of the semiotic in poetic language allows the poet to connect language to that semiotic space less regulated by patriarchal social structures. This Kristeva associates with our pre-Oedipal existence. This is where the similarity ends. Since, according to Kelly Oliver, Kristeva believes that "revolutionary texts prepare subjects for social changes that shake the foundation of contemporary society" (Oliver: 100-1), and this contrasts with Heaney, as Kristeva urges this internal revolution to carry influence into the political realm.

According to Heaney, poetry has no power to effect mass social change, and he states that those who would wish poetry to become a force of political change constrain art. These people he terms "hecklers":

Our heckler ... will want poetry to be more than an imagined response to conditions in the word; he or she will urgently want to know why it should not be an applied art, harnessed to 
movements which attempt to alleviate those conditions by direct action (Heaney 1986: 2).

Kristeva exemplifies the "heckler" of poetry. Not without reason, though, does she urge poetry to become a political agent of change. As Oliver asserts, Kristeva believes that "by changing the representation through which we live ... our lives can change" (Oliver 1993: 11) so through a "dialectic oscillation" (ibid.) between the semiotic and the symbolic present in poetic language, the speaking subject uses a revolutionary language with the potential to enact political change.

The notion in Heaney's The Redress of Poetrythat poetry can be healing or "strong enough to help" (Heaney 1989: 9) offers an interesting approach to the reading of Heaney as a poet and person in constant redress. Furthermore, Human Chain is written in a "conscious dialogue" (Matthews 2010: 1) with Heaney's previous work, indicating that this final volume is a mediation on the span of his entire life and work. The attention that is brought to Heaney's relationship with his father in Human Chain indicates that the normative model of the father-son relationship customary to Heaney is lacking. In Heaney's work, there are indications of his desire to redress the opposition of the maternal/paternal roles.

Many of the poems in Human Chain regarding Heaney's father and himself are "second thoughts" (Vendler 1998: 74); they return to memories to reflect and redress. In part "IV" of "Album", Heaney discusses the three times he embraced his father and the awkwardness of the emotion. Having "once said that his language and sensibility are yearning to admit ... a transcendent dimension" (Farndale 2001), we see the evolving expression of the semiotic in "Album". The self-reflection and redress are seen in the lines:

Were I to have embraced him anywhere It would have been on the riverbank

That summer before college, him in his prime,

Me at the time not thinking how he must

Keep coming with me because I'd soon be leaving. (Heaney 2010: 1-5)

The distance between stanzas becomes loaded with absence, signifying the distance between Heaney and his father and the emotive distance of an embrace that did not happen. The rhythmic flow of language in lines three and four demonstrate the slippery nature of time.

Helen Vendler notices a shift in Heaney's style after his father's death, claiming that Heaney has a "new interest in the virtual realm, in which absence, not presence, defines space" (Vendler 1998: 76). In his own words, Heaney states that "abstract words that had previously had an ephemeral flimsiness to them were no longer abstractions" (Farndale 2001), thus, poems like "The Butts" in Human Chain are filled with emotive absences that strive to express the unspeakable chora. Inside the absences there are traces of a former man, "chaff cocoons" (Heaney 2010: 22) remain inside his father's pockets, like ghostly seeds, symbolising the essence of his father and his ephemeral presence. There is, as well, the same sense of regeneration that is found in "A Kite for Aibhín". The chaff's ability to grow anew when planted is similar to the kite's windfall moment and signifies the larger symbolism of the human chain Heaney's collection refers to.

Furthermore, Heaney's negotiation of language is an "encounter with the law of the father" (Smith 1998: 18). Heaney says that, to his father:

silence was valued, speech was almost a devaluing of the thing; ... it was to do with my father... there was a code, and you knew the code of you didn't. If you knew how to conduct yourself properly, you didn't talk too much about yourself and your feelings (Farndale 2001).

His poetry becomes a way to overcome the regulatory law of the father that suppresses language and leads to the silences that represent Heaney's relationship with his father.

Emotive speech between Heaney and his father literally orientates around the mother. In that same interview with Nigel Farndale, he asks Heaney, "So what did they talk about, father and son?" (Farndale 2001). Heaney's reply was that "the way he indicated equality, at easeness, was to talk about my mother" (ibid.), here, the two men orientate expressive and emotional language through the mother; it is as though, she becomes a vehicle for the semiotic. Speaking of his cottage in Wicklow, Heaney said: "the place had, and still has, no telephone lines ... When I go there I feel gathered 
and safe and under cover" (ibid.). This description of the home as a speechless and safe place is reminiscent of the maternal chora or the Freudian in utero existence. Additionally, his cottage where he writes is a womb-like site, where he can experiment linguistically and safely with the semiotic, and where his language only becomes an utterance once published.

"Antaeus" and "Hercules and Antaeus" two poems in North (1975) employ the commonly used mother-earth literary trope to dramatize the battle between the symbolic represented by Hercules and the semiotic represented by Antaeus. In these poems, Heaney writes about Antaeus a mythological figure who is invincible when connected to the womb-like earth and the hyper-masculine Hercules, who is determined to break Antaeus's connection with the earth and bring him into a symbolic sphere. In "Antaeus" the earth is nourishing, but problematically instinctual, primitive and dark, and thus must be transcended to the masculine realm of air which is constituted by rationality and progress. When read as poems in dialogue with each other, "A Kite for Aibhín" and "Hercules and Antaeus" bring certain unities to light. For instance, the last lines echo each other: "my elevation, my fall" (Heaney 1975: 20) and "the kite takes off, itself alone, a windfall" (Heaney 2010: 19). In "Antaeus" the broken connection with the earth and the transcendence into a realm of patriarchal regulation is a downfall. Whereas the relationship depicted between earth/family regulation and kite/human in "A Kite for Aibhín" is more nuanced. The kite still maintains a connection with the earth, though string has broken and the kite is alone, Heaney evokes the sense that the connection with the earth can still be reinstated. The "windfall" here is regenerative. The kite is brought back to the earth but still maintains the ability to fly. This poem marks a revolution in Heaney's depiction of the maternal. The kite moves "between worlds ... tugg[ing] between earth and sky" (Johnston 2010) here, and air, instead of being patriarchal and rational, has become a maternal space and the earth has become an inclusive site where both genders become part of the maternal sphere. The hierarchy of the earth-woman and man-sky opposition has been obliterated.

Moreover, Helen Vendler suggests that Heaney has "looked to myth for an alter-ego" (Vendler 1998: 89) and is sympathetic towards Antaeus. Thus, as a mythic figure who gains strength from the maternal, "cradled in the dark that wombed me / and nurtured in every artery" (Heaney 1975: 10-11), Heaney resists the notion that one should transcend wholly into the symbolic realm of patriarchy. This is reminiscent of Kristeva's notion that is it the maternal body that orientates drives. Noëlle McAffee notes that this "wealth of drives ... could be extremely disorientating and destructive were it not for the infant's relation with his or her mother's body" (McAffee 2004: 19). Heaney develops Kristeva's ideas into a more inclusive regulatory system. Heaney states that "my hand is like a spindle / Unspooling the kite" (Heaney 2010: 13-4) with the presence of "the gazing face and heart of the kite flier" (Heaney 2010: 17), creating a combined site of regulation represented as an intensely caring site of familial guidance.

Part "V" of "Album" in Human Chain exemplifies how the expression of small familial pleasure for both Heaney and his father is found later in life. Heaney writes: "It took a grandson to do it properly / to rush him in his armchair ... proving him thus vulnerable to delight" (Heaney 2010: 1-4). For Heaney's father, it took a generational difference, becoming a grandfather, to express such maternal delight. This "snatch raid on his neck" (Heaney 2010: 3) in its suddenness dissipates the gap between regulated behaviour and delight which stems from the semiotic chora. The symbolic while necessary for ordering language becomes a restrictive patriarchal device. Seemingly, the patriarchy inherent in prosaic and everyday language prevents men, as upholders of language, from expressing the maternal drives of the semiotic chora.

To elucidate this point further, in "A Kite for Michael and Christopher', a midlife poem, the language is considerably more patriarchal and isolating than in "A Kite for Aibhín". Morisco describes the kite in this poem as "a metaphorical lesson for life ... to have the strength to endure the pain caused by the taut, thin, cutting string in one's hands" (Morisco 
2013: 39). This poem is also about Heaney's own father adding to the feeling that this poem is a negotiation of how men feel able to express love and what they can offer in the father role. For Heaney, love is expressed through lessons, the role of the father being regulatory or of providing training:

Before the kite plunges down into the wood and this line goes useless

take in your two hands, boys, and feel

the strumming, rooted, long-tailed pull of grief.

(Heaney 1984: 17-20)

The poem which ends with the boys being directed to "take the strain" (Heaney 1984: 23) reflects a man who is warning his children of life's grievances, of the strains of shouldering burdens and of mortality. Here Heaney represents the oppressive social regulating force of the father and the symbolic. Heaney's instruction is a re-enactment of the Oedipal moment. The lessons he provides in his role as father enforce the reality principle which, according to Freud, is to remind the child that instant gratification - for example, the breast will not always be there; that life, instead of pleasure, is full of inevitable strains. Additionally, the overwhelming sense of the kite plunging towards an inevitable collision is evocative of Freud's death drive. This is particularly apt when we consider the tension in the string of a kite and that the death drive "strives towards the reduction of tensions to absolute zero" (Thurschwell 2000: 86). Additionally, the repetition of "I'd" in lines four to six suggest an ingrained experience and the teachings his own father passed down to him. It transitions from seeing, to tapping, to tying; the progression between passively watching and then creating the kite indicates Heaney's transformation from son to father:

I'd seen it grey and slippy in the making

I'd tapped it when it dried out white and stiff,

I'd tied the bows of newspaper

(Heaney 1984: 4-6)

This urge to repeat is present in Heaney's compulsion to return to the image of the kite. It is rooted in a significant act and image in both childhood and adult memories. The poetic return to the kite motif signifies an analysis of his memory and of the significance he posits on the kite. This analysis leads to the reformed tone in the last kite poem.

Heaney's final kite poem is a lesson in the importance of the interplay between the symbolic, semiotic and maternal. Heaney, as the coherent speaking subject, expresses his joyfor the "not yet articulated" (Kristeva 1984: 94) child. This child who is "not yet constituted" (Kristeva 1984: 93) is literally "arranged ... by family" (ibid.) and brought into a warmer, less isolated symbolic realm than the one articulated in Michael and Christopher's kite poem. In stark contrast, the tone in "A Kite for Aibhín" remedies his previous gravity, and exhibits more subtly the fragility, as well as the beauty and joy, of human life. "The kite a thin-stemmed flower" (Heaney 2010: 14) shows how Heaney creates a sense of harmony between human drives. While the poem possesses the potential for death, due to the kite's precarious state in the sky, the overwhelming tone of this later kite poem is of absolute joy.

Kristeva asserts that in poetic language the presence of the semiotic chora is marked by the disruption of orderly and limited meaning:

When the semiotic chora disturbs the thetic position by redistributing the signifying order, we note that the denoted object and the syntactic relation are disturbed as well. The denoted object proliferates in a series of connoted objects produced by the transposition of the semiotic chora (Kristeva 1984: 108).

What is crucial here is the notion of the denoted objects "proliferation"; in other words, the poet's successful negotiation between semiotic and symbolic means that "the sentence is not suppressed, it is infinitized ... it proliferates in mimetic, fictional, connoted objects" (Kristeva 1984: 109), thus, it stands to reason that the reader should be able to take one Heaney poem and discover meaning "ad infinitum" (Kristeva 1984: 109). To elucidate this point further, the connotations and allusions which can be gleaned from one phrase taken from "A Kite for Aibhín': "our long-tailed comet" (Heaney 2010: 9) are numerous. The phrase is both image and metaphor, figurative child and literal kite. It alludes to the process of insemination; the "long-tailed comet" is evocative of seminal fluid, and this image of spermatozoa is well situated in a poem about birth. The long-tail of the comet suggests a 
genealogy; a narrative lineage which follows the child as she embarks upon the descent of her own history as well as the repetition of the kite motif in Heaney's work relating to family. A consideration of the symbol of the comet in literature illuminates further meanings. When considering that this is Heaney's late work, the comet then brings to mind Dylan Thomas's "Do not go gentle into that good night'. The lines, "Grave men, near death, who see with blinding sight / Blind eyes could blaze like meteors and be gay" (Thomas 1951: 13-14) uses the image of the meteor to suggest a clarity and alertness that has come with old age. Thomas suggests that, when we are near death or in our old age, we are afforded the ability to reflect and understand our lives.

In William Blake's Milton, "each time a meteor appears ... it symbolizes poetic inspiration and embodies the soul of the great English poet" (Olsen and Pasachoff 1998: 111), the birth of Heaney's granddaughter and Pascoli's "L'Aquilone" act as the lightning flash of the muse. In Heaney's Station Island he speaks of "a revelation / set among my stars" (Heaney 1985: 36-37) where James Joyce speaks to him, acting as a guide and providing an epiphany. Conversely, apocalyptic meaning has been affixed to the symbol of the comet in literature and like the kite, there is the same fear of collision and destruction attached. The comet and the kite are all on an apocalyptic path. Here we can see the association between this symbol and Freud's death drive, as well as Kristeva's chora whose destructiveness "is the drive's most characteristic trait" (Kristeva 1984: 95).

There are some intriguing resemblances to be found between Heaney's kite and Kristeva's chora. Air, like Kristeva's chora, cannot be given an axiomatic form. Air, symbolic here of the chora, becomes the "rhythmic space" (Kristeva 1984: 94) where the kite, in an allusion to human circadian rhythms, is subject to "drives" (ibid.) characterised by the kite, which "hovers, tugs, veers, dives" (Heaney 2010: 10), Heaney utilises a sibilant rhythm lending an erratic musical quality to the poem.

Kristeva's definition of the chora as "a non expressive totality formed by the drives and their stases in a motility that is as full of movement as it is regulated" (Kristeva 1984: 93) finds a fitting metaphor when likened to the kite. The kite moves both by the air, which I shall constitute as drives, and the regulating order of the hand, "like a spindle / Unspooling" (Heaney 2010: 13-4), representative of the symbolic. There is no working kite without wind, in the same way, that without the semiotic, there can be no meaningful symbolic. The maternal body, cradling a newborn child, is present within the poem and becomes emblematic of the relationship between the maternal body and the chora. Here, the child is pre-Oedipal and pre-mirror stage. The child, then, in McAffee's opinion is in "the warm cocoon of the chora" (McAffee 2004: 22):

The longing in the breast and planted feet And gazing face and heart of the kite flier Until string breaks and - separate, elate -

The kite takes off, itself alone, a windfall.

(Heaney 2010: 16-9)

In the empty space, between the umbilical break of the kite string and the subject entering lone existence, the chora is symbolically represented. In that empty space between language, the entire experience of human life is compressed.

Freud's suggestion that "the intensity of castration fear is so excessive that it equals the fear of death" (Grof 2000: 114) is represented in another moment of emptiness. Heaney writes that the kite "goes with the wind, until" (Heaney 2010: 11) this empty space, constructed by Heaney's line-break, creates an allusion to death through the castration of the line and the creation of a void that represents the presence of the "chora, which is on the path of destruction, aggressivity and death" (Kristeva 1984: 95). Heaney's language, whilst alluding to death, presents the moment of rupture as joyful rather than traumatic. The "string break" (Heaney 2010: 18) is characterised by Heaney as "separate, elate" (ibid.), evoking an image of birth and lone existence as a moment of elation. For those who watch as "the kite takes off, itself alone, windfall" (Heaney 2010: 19) this is the first moment of individual agency.

Heaney's imagery of the sky mirrors a seascape, "Pale blue heavenly air is supporting / A white wing beating high against the breeze" (Heaney 2010: 2-3). The white wing evokes surf, softly folding down onto a blue ocean. Within the context of the poem's maternal 
feeling, this imagery is akin to Freud's "oceanic" feeling. This oceanic state is the time when all needs are met; in other words, the child is in "a realm of plenitude" (McAffee 2004: 33). This period, for Freud, exists in utero and ends when the child is weaned from the breast. Thus, the images in Heaney's poem arouse this sense of Elysian bliss, marking the return to the realm of drives and energies which constitute the chora.

Ultimately, "A Kite for Aibhín" is a poem of redress focusing on human relationships and
Heaney's capacity to express maternal feeling. The revolution in tone and attitude that occurs between the two kite poems indicates the revolution of spirit that has occurred for Heaney. As Vendler states "it is very difficult for poets ... of rooted heaviness, like Heaney, to become light, airy, desiccated" (Vendler 1988), yet, in "A Kite for Aibhín" through the use of the semiotic Heaney has managed to articulate successfully an inclusive maternal realm comprising both earth and sky.

\section{Works Cited}

Farndale, Nigel. 2001. "Seamus Famous" The Telegraph. http://www.telegraph.co.uk/culture/4722682/SeamusFamous.html [retrieved: 07/01/2015].

Heaney, Seamus. 1975. North. London: Faber \& Faber. 1984. Station Island. London: Faber \& Faber. 1995 (1989). "The Redress of Poetry - Oxford Lectures" London: Faber \& Faber. 2010. Human Chain. London: Faber \& Faber.

2012. "A Foreword to The Kite" Griselda Online: Portale di Letteratura. http://www.griseldaonline.it/sonde/heaney-kite-pascoli-aquilone.html[retrieved: 13/01/2015].

Higgins, Geraldine. 2014. "Feeling into Words: Remembering Seamus Heaney" in Irish Studies South1.1. 72-7. http://digitalcommons.georgiasouthern.edu/cgi/viewcontent.cgi?article=1017\&context=iss [retrieved: 17/02/2015]

Johnston, Maria. 2010. "Human Chain by Seamus Heaney” Tower Poetry. 1-5 http://www.towerpoetry.org.uk/images/stories/Reviews/Heaney_Human_Chain_Johnston_Oct_2010.pdf [retrieved: 25/01/2015]

Kristeva, Julia. 1974. "Revolution in Poetic Language" (extracts) in Toril Moi (ed. and trans.) 1986. The Kristeva Reader. Oxford: Blackwell.

Matthews, Steven. 2010. "Bringing Home, Letting Go" in Poetry Review 100.2. 1-4

McAffee, Noëlle. 2004. Julia Kristeva: Routledge Critical Thinkers. Abingdon: Routledge.

Morisco, Gabriella. 2013. "Two Poets and a Kite: Seamus Heaney and Giovanni Pascoli” in Linguae \&12.1. 3545.

Oliver, Kelly. 1993. Reading Kristeva: Unravelling the Double-Bind. Bloomington: Indiana University Press.

Olsen, Roberta. J. M and Pasachoff, Jay. M. 1998. Fire in the Sky: Comets and Meteors in the Decisive Centuries, in British Art and Science. Cambridge: Cambridge University Press.

Pascoli, Giovanni and Heaney, Seamus. (trans.) n.d. (1904). "L'Aquilone” translated by Seamus Heaney. http://www.griseldaonline.it/sonde/heaney-kite-pascoli-aquilone.html [retrieved: 7/01/2015].

Smith, Anne-Marie. 1998. Julia Kristeva: Speaking the Unspeakable. London: The Pluto Press.

Sonzogni, Marco. 2014. "Note on Heaney and Pascoli” in Irish Studies South1.1. 35-6 http://digitalcommons.georgiasouthern.edu/iss/vol1/iss1/13[retrieved: 25/01/2015].

Thomas, Dylan. 2000 (1951). Selected Poems. London: Phoenix.

Thurschwell, Pamela. 2009 (2000). Sigmund Freud: Routledge Critical Thinkers Second Edition. Abingdon: Routledge.

Vendler, Helen. 1998. Seamus Heaney. United States: Harper Collins Press.

. 1988. "Second Thoughts'. New York Review of Books. http://www.nybooks.com/articles/archives/1988/apr/28/second-thoughts/ [retrieved: 27/01/2015].

Received 17 February 2016 Last version 28 February 2016

Hannah Spruce has a Master's degree in Contemporary Literatures from Leeds Beckett University. Her Master's dissertation focused on identity and materiality in old age and her current research focuses on the shift towards a new maternal language in Seamus Heaney's oeuvre. 